\title{
Farmers' Need for an Agricultural Meteorological Information System in a Tropical Wet and Dry Climate: Imo as a Case Study
}

\section{Okpara Okechukwu Dominic}

National Weather Forecasting and Climate Research Centre (NWFCRC), Nigerian Meteorological Agency (NIMET) Headquarters, Nnamdi Azikiwe International Airport, Abuja-FCT, Nigeria

Email address:

chukwuebube@gmail.com (O. D. Okpara)

\section{To cite this article:}

Okpara Okechukwu Dominic. Farmers' Need for an Agricultural Meteorological Information System in a Tropical Wet-and-Dry Climate: Imo as a Case Study. American Journal of Agriculture and Forestry. Vol. 3, No. 5, 2015, pp. 202-207. doi: 10.11648/j.ajaf.20150305.15

\begin{abstract}
In this paper, the Agricultural Meteorological Information System needs for rural farmers in Imo State, Nigeria, was determined in a survey of five hundred farmers using purposive sampling method and structured questionnaires. The study was able to reveal that there was need for the establishment of effective Agricultural Meteorological Information System support for enhanced agricultural productivity in Imo State. The survey also showed that the rural farmers showed great interest in using weather information for cultivation, and they also have high preference for the reception of agricultural meteorological information through their mobile phones over any other medium of information delivery in the rural areas.
\end{abstract}

Keywords: Agricultural Meteorology, Agricultural Meteorological Information System, Purposive Sampling, Imo State Farmers

\section{Introduction}

Information needs can be defined as the state of lack of desirable requisite(s) or commodity - information necessary to deal with a situation as the individual sees fit [1]. Agriculture is interdisciplinary in nature, and for it to be fully developed, farmers need information from different disciplines [2].

According to [3], information needs arise when a person recognizes a gap in his/her state of knowledge and wishes to resolve that anomaly. Sometimes, farmers do not always know what their information needs are. They do not know they have an information gap. It could be that they are not aware that there is information out there that could help them to a great deal. They also do not know that new information has rendered obsolete what they previously knew. It is only when they are exposed to the relevant information that the need is recognized.

The guide to agricultural meteorological practices [4] prepared by the WMO Commission for Agricultural Meteorology, underlines in each chapter how agricultural meteorology depends on the combination of meteorological and biological data as well as on the agricultural practices.

Based on agricultural information sources used by farmers in Imo State, agricultural information which include information on pest and weed control, weather forecast, credit facilities, fertilizer and legislations on agriculture is generally generated in universities and research institutes [5].

It is assumed that the provision of agricultural meteorological information and services successfully reach small scale farmers in rural areas through agricultural extension services while this has not been the case [6]. The dissemination of agricultural meteorological information to farmers is difficult in practice [7]. However, the use of emerging and evolving technologies such as smart (mobile) phone applications has helped farmers to increase their farm efficiency while reducing their cost of production [8].

A similar study which identified the information needs for climate change adaptation among rural farmers in Imo State using structured questionnaires, interview schedules and data elicited from 120 farmers in the state has been carried out [9].

The study area of this research is Imo State. Imo State is one of the 36 states of Nigeria and it is located in the southeast of Nigeria with Owerri as its capital. Imo State is located with coordinates: $5^{0} 29^{\prime} \mathrm{N} / 5.483^{\circ} \mathrm{N}$ latitude and $7^{0} 2^{\prime} \mathrm{E} / 7.033^{\circ} \mathrm{E}$ longitude with a total area of 5,530 square kilometers $\left(\mathrm{km}^{2}\right)$ [10]. 
The study area is shown in Fig. 1.

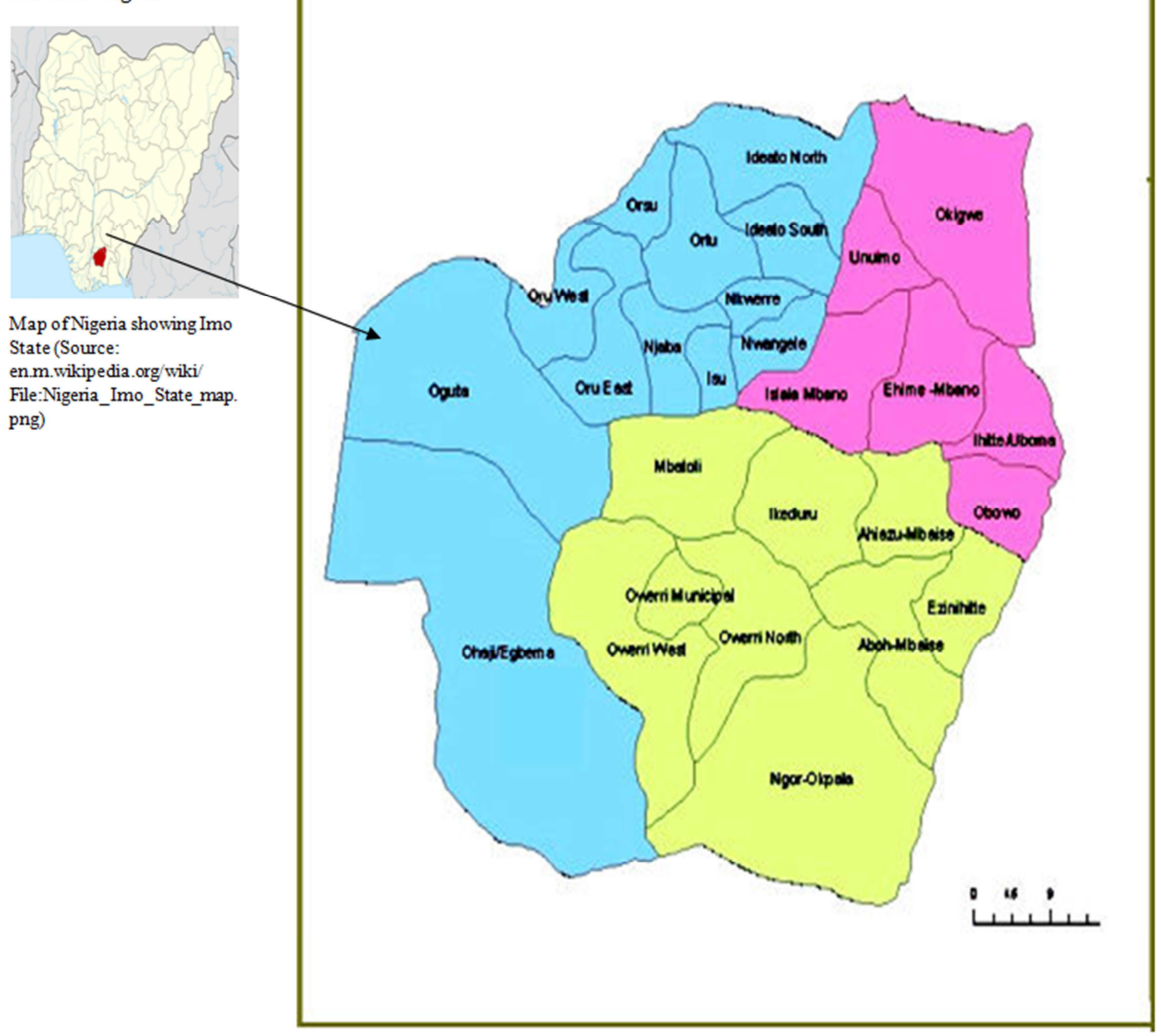

Map of Imo State showing the 27 Local Govemment Areas. (Source: wwwinformationng.com)

Fig. 1. The study area-Imo State.

\section{Materials and Methods}

The survey involved purposive sampling which means that the way sampling was done was tied to the objectives of the study, and the sampling strategy dependent on the context in which the survey was carried out and the nature of the research objectives.

Structured questionnaires were used for the collection of data during the survey. The phone numbers of all the farmers were collected and were used in contacting any of them during the verification of data, and collection of addition information from them.

At most, 18 respondents were selected from each of the twenty-seven (27) Local Government Areas of Imo State, except in the Owerri Municipal where thirty-two (32) respondents were selected. The respondents were mainly small-scale farmers. Most of them were selected from a farmers' association in the study area.

Some of the questions that were presented in the structured questionnaires are summarized as follows:

1. How would you use weather information?

2. How would you like to receive agricultural meteorological information?

3. What problems do you encounter in using weather information?

4. What would you like the agricultural meteorological 
computer information system to do for you?

The respondents were allowed to make multiple selections according to their choices in the questionnaires, in order to avoid ambiguity in their choices.

Table 1 shows a list of the 27 Local Government Areas of Imo State.

Table 1. The 27 Local Government Areas (L.G.A.) of Imo State.

\begin{tabular}{ll}
\hline Serial Number & Local Government Areas \\
\hline 1 & Aboh Mbaise \\
2 & Ahiazu Mbaise \\
3 & Ehime Mbano \\
4 & Ezinihitte \\
5 & Ideato North \\
6 & Ideato South \\
7 & Ihitte/Uboma \\
8 & Ikeduru \\
9 & Isiala Mbano \\
10 & Isu \\
11 & Mbaitoli \\
12 & Ngor Okpala \\
13 & Njaba \\
14 & Nkwerre \\
15 & Nwangele \\
16 & Obowo \\
\hline
\end{tabular}

\begin{tabular}{ll}
\hline Serial Number & Local Government Areas \\
\hline 17 & Oguta \\
18 & Ohaji/Egbema \\
19 & Okigwe \\
20 & Onuimo \\
21 & Orlu \\
22 & Orsu \\
23 & Oru East \\
24 & Oru West \\
25 & Owerri Municipal \\
26 & Owerri North \\
27 & Owerri West \\
\hline
\end{tabular}

\section{Results}

\subsection{Weather Information Usage}

Most of the farmers (85\%) preferred using weather information for cultivation as shown in Fig. 2. Twenty-five percent $(25 \%)$ of the farmers indicated that they would use weather information for pesticide/insecticide applications compared with $15 \%$ of the farmers who would use the same information for marketing of their agricultural products.

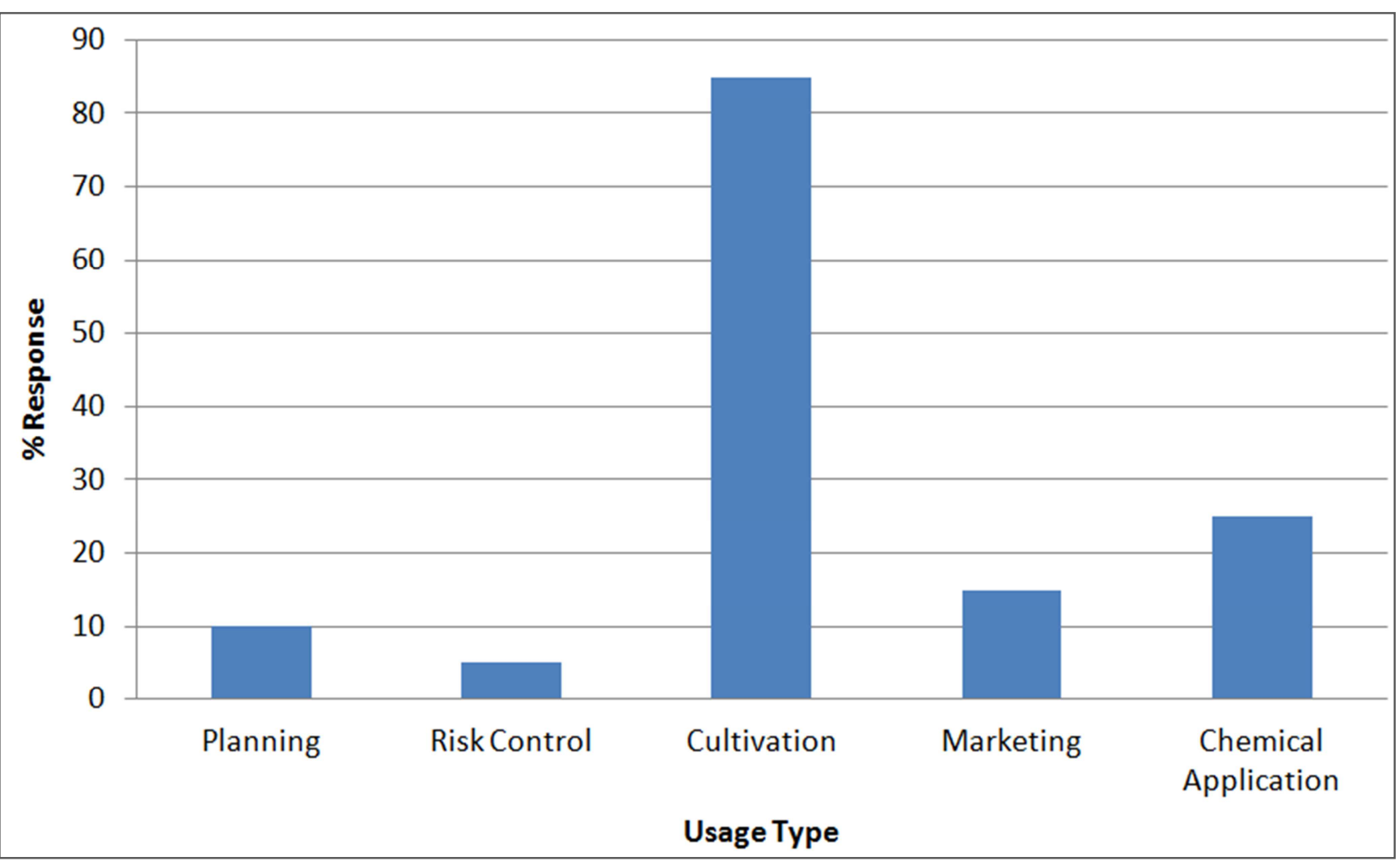

Fig. 2. Distribution of farmers by use of weather information.

\subsection{Dissemination of Information}

As shown in Fig. 3, over 90\% of the farmers preferred to receive agricultural meteorological information through SMS because of ease of access with mobile phones, followed by $58 \%$ of the farmers that preferred regular visits by agricultural extension officers. $23 \%$ of the farmers preferred radio reception because radios are very affordable to the masses. 


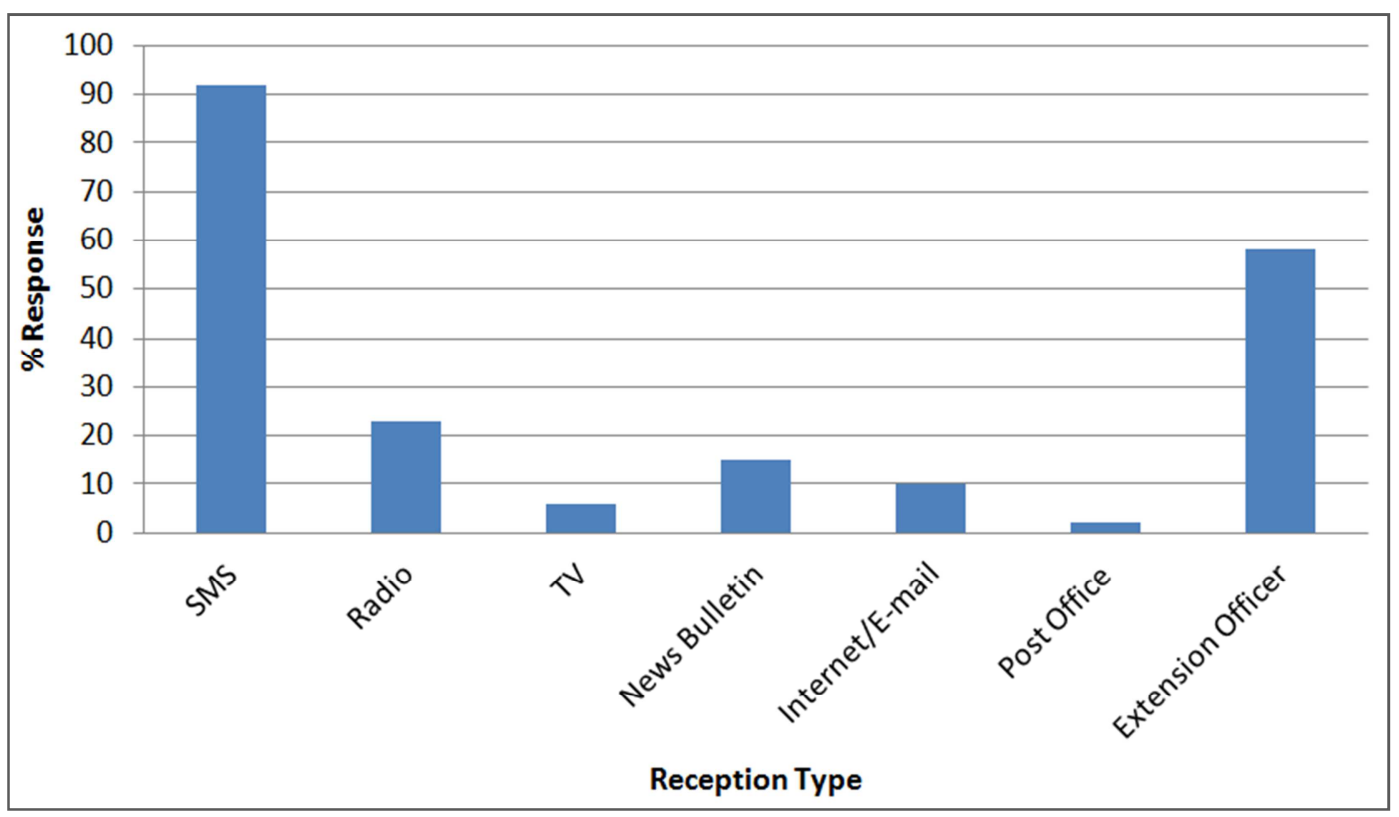

Fig. 3. Distribution of farmers by preference for receiving agricultural meteorological information.

\subsection{Problems Encountered in Using Weather Information}

From Fig. 4, it can be seen that majority of rural farmers in remote locations are not able to access weather information most of the time. Sixty-four (64\%) said they were not able to access weather information because they do not have TV, radio or internet at all times. Forty percent $(40 \%)$ lacked the ability to interpret weather information. Thirty-three (33\%) said the weather forecasts or predictions were unreliable. While $9 \%$ of the respondents said they were not able to access weather information.

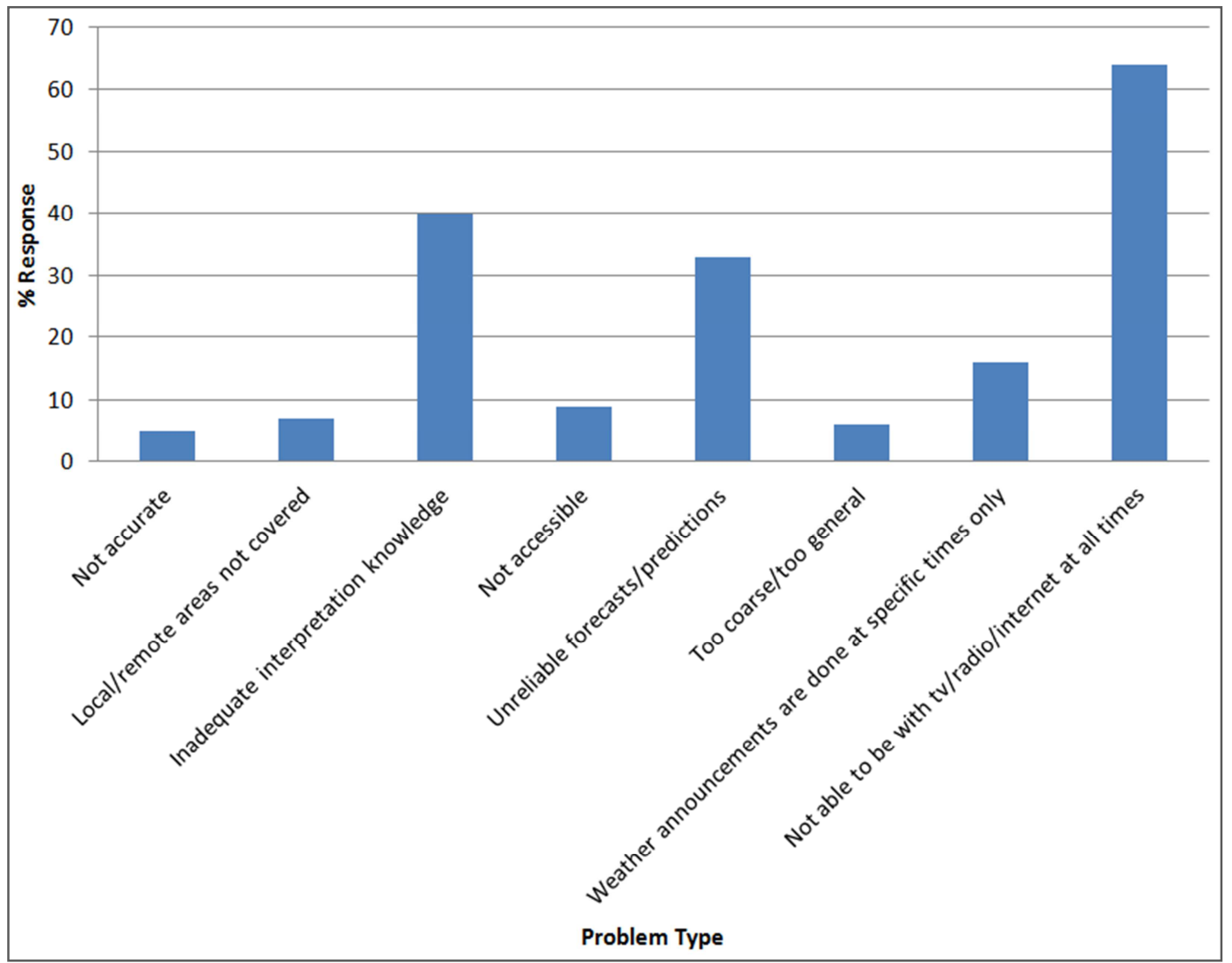

Fig. 4. Distribution of farmers by problems encountered in using weather information. 


\subsection{Role of the Agricultural Meteorological Information System (AMIS)}

From the results in Fig. 5, it can be observed that $88 \%$ of the respondents indicated that the AMIS should address crop and farm planning issues. Followed by $52 \%$ of the farmers who wanted it to provide interactive communication. Farmers that wanted the AMIS to help in answering inquiry questions constituted the least proportion $(6 \%)$. Between just 3 percentage point margin $(19 \%-16 \%)$, the farmers wanted the AMIS to help in marketing of their products (19\%), provide news updates $(18 \%)$, obtain relevant meteorological data (17\%), and provide forecasts $(16 \%)$.

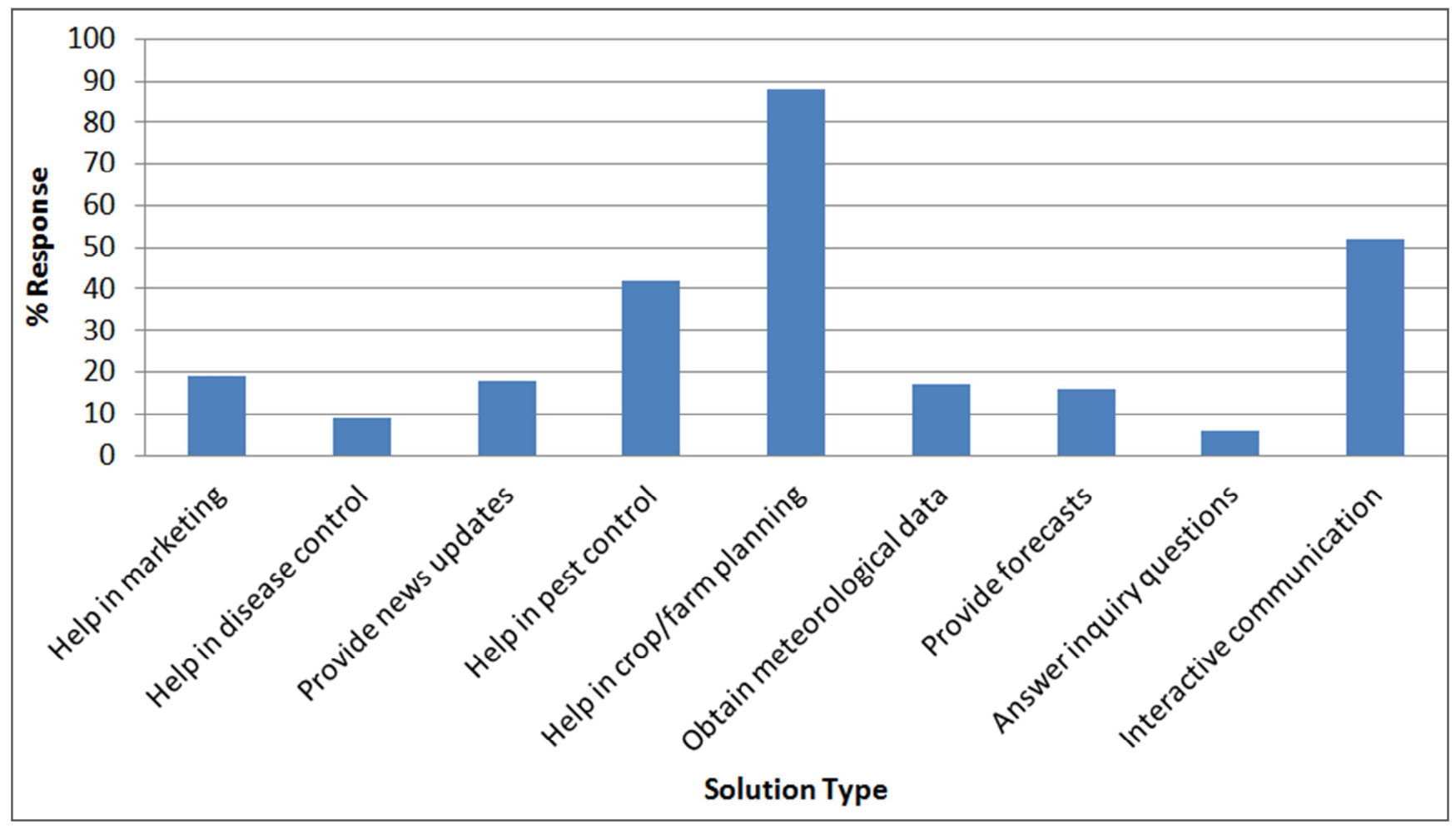

Fig. 5. Distribution of farmers by software solution proffered by the AMIS.

\section{Discussion}

From the results, majority of the problems encountered by the farmers in using weather information are due to their inability to be near their television or radio sets during weather announcement periods; most of them do not have any device that they can use to browse the internet for weather information. These problems are peculiar to poor rural farmers in the region. Many of the farmers do not know how to interpret the weather information to suit their needs because of their level of education. Some also do not apply the available weather information to their agriculture practices because they said the information provided are often unreliable.

Furthermore, rural farmers use weather information more for crop cultivation purposes, while few use the same information for their farm risk control. They mostly prefer to obtain agricultural meteorological information through both SMS and agricultural extension officers. Customized agricultural weather information is more accessible via SMS by rural farmers because of the availability of cheaper mobile phones to them. Also SMS messages are much quicker and easier to obtain. Preference for extension officers is also important because many of the farmers valued interpersonal relationships and communication over non-human technological communication.

These results are slightly comparable to those obtained by [5], from a sample of 1386 farmers across the 34 farm blocks and 63 farm cells in the Agricultural Development Programme (ADP) zones of Imo State. High number of farmers receiving agricultural meteorological information through SMS means that dissemination of the information through mobile phones is more preferable to other options. Respondents showed reservations with information reception via the post office because of the poor postal services in the state; and also, small percentage of farmers, especially those that have no electronic devices, preferred news bulletins.

\section{Conclusion}

Most of the respondents needed efficient computer software that can retrieve or acquire, interpret, process and send the relevant agricultural meteorological information to them via SMS from any location. They also expect to obtain useful weather information that they can apply to their crop/farm planning and in pest control, as well as being able 
to interact with the software service, for instance, being able to query the software database for detailed information about a particular crop and the crop's associated pests using their mobile phones.

\section{Acknowledgements}

Thanks to Ms. Esther of Agbekoya Farmers Association, No. 23 Wetheral Road Owerri, Imo State, for helping me in administering the questionnaires to the farmers of the association.

\section{References}

[1] A. M. Kaniki, Agricultural information user population and critical task in Africa, in: L. O. Aina, A. M. Kaniki, and J. B. Ojiambo, (editors). Agricultural information in Africa, Ibadan, Nigeria, Third World Information Services. 1995, pp. $12-31$.

[2] S. LawalIro, B. Y. Boadi, O. Oladokun, T. Kalusopa, "The Generation and Dissemination of Agricultural Information to Farmers in Nigeria: A Review," International Organization of Scientific Research (IOSR) Journal of Agriculture and Veterinary Science. Vol. 7, No. 2, Ver. I(Mar-Apr. 2014), pp. 102-111.

[3] D. Nikolas, Assessing information needs: Tools, Techniques and Concepts for the Internet Age, 2nd ed. ASLIB Taylor and Francis e-library. 2005.

[4] World Meteorological Organization. Guide to Agricultural Meteorological Practices, 2010 Edition, updated 2012. WMO, 7 bis, avenue de la Paix, Geneva, Switzerland. WMO-No. 134, pp. 1-799.

[5] U. N. Opara, "Agricultural information sources used by farmers in Imo State, Nigeria," Information Development. Sage Publications. Vol. 24, No. 4, 2008, pp. 289-292.

[6] S. Kinuthia, Agro-meteorological aspects in sustainable agricultural development. Review of the agro-metrological applications to conserve and manage natural resources for the benefit of agriculture, range lands, forestry, fisheries and other natural resources in Kenya, 2008. Retrieved from http://www.wamis.org/agm/meetings/etasad08/etasad_Kinthui a.pdf, (accessed June 2014).

[7] WMO/CTA. La radio rurale et la diffusion des informations agrométéorlogiques. Compte-rendu d'un atelier tenu sur invitation du Gouvernement du Mali, Bamako. May 1992, pp. 18-22. OMM, Genève, 339.

[8] M. Valipour, "Need to update of irrigation and water resources information according to the progresses of agricultural knowledge," Agrotechnology. S10:e01, 2013. Doi: 10.4172/2168-9881. S10-e001.

[9] P. C. Umunakwe, F. N. Nnadi, J. Chikaire, C. D. Nnadi, "Information needs for climate change adaptation among rural farmers in Owerri West Local Area of Imo State, Nigeria," Agrotechonology. Vol. 3, p. 118, 2014. Doi:10.4172/21689881.1000118.

[10] Wikipedia. org. Imo State. Retrieved from en.m.wikipedia.org/wiki/Imo State (accessed on 23/07/2015).

\section{Biography}

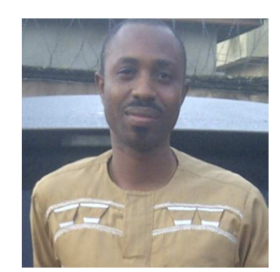

Okpara Okechukwu D.

Okpara Okechukwu D. is a physicist and meteorologist. He works at the Nigerian Meteorological Agency (NIMET), PortHarcourt International Airport, Nigeria. He is also an independent researcher. 